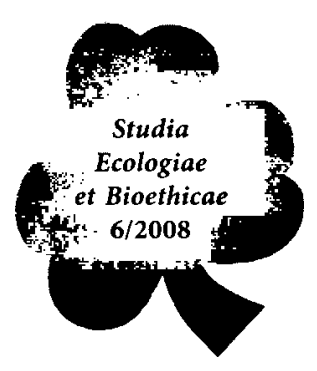

\title{
O źródłach teorii przyczynowania celowego w tomizmie konsekwentnym
}

\section{Historyczne ujęcie konsekwencji przyczynowania celowego w strukturze bytu}

Celem artykułu jest ukazanie źródeł koncepcji przyczynowania celowego sformułowanego przez M. Gogacza. W tomizmie konsekwentnym przyczyny celowe to byty przygodne, które odpowiadają za kształtowanie się istoty bytu powstającego. To one decydują o jego zawartości treściowej, czyli o tym jaki ten byt będzie. Powodem, dla którego podjęto się takiej analizy, jest to, że M. Gogacz w żadnej ze swych publikacji nie ujawnił jakie jest filozoficzne źródło tej koncepcji. Wnikliwa analiza tekstów źródłowych - Arystotelesa i Tomasza z Akwinu, jako tych, którym Tomista poświęca znaczną część swych sił filozoficznych, naprowadziła nas na rozumienie przyczynowania celowego u tych dwóch filozofów. Okazało się, że przyczynowanie celowe w tomizmie konsekwentnym to $z$ jednej strony przyczynowanie celowe w sensie Arystotelesowym, ponieważ przyczyny celowe są jakby wzorem, modelem, na miarę którego kształtuje się istota bytu powstającego; a $\mathrm{z}$ drugiej strony są one Tomaszowymi przyczynami wtórymi, które sam Akwinata zalicza do przyczyn sprawczych. To połączenie dwóch rozumień dało w konsekwencji nową teorię przyczynowania celowego. Jednak analiza tych trzech koncepcji, ujawniła wiele różnic w samym rozumieniu przyczyny celowej, strukturze bytu przygodnego, charakterze przyczynowania sprawczego oraz przyczynowania celowego. Choć terminologia jest ta sama, to inne jest rozumienie oraz kontekst poruszanych zagadnień. Widoczne jest to zwłaszcza w samym rozumieniu przyczynowania celowego, jako tego, którego konsekwencje dają się wykryć w istocie bytu przygodnego. Pytanie, na które postaramy się odpowiedzieć w tym artykule, dotyczy z jednej strony „tajemniczych” źródeł teorii przyczynowania celowego w tomizmie konsekwentnym, a z drugiej strony postaramy się odpowiedzieć czy ostatecznie mamy do czynienia z jedną koncepcją, czy $\mathrm{z}$ trzema odmiennymi. W tym celu najpierw przedstawione zostanie rozumienie przyczynowania celowego u Arystotelesa, następnie u Tomasza z Akwinu, by na koniec pokazać koncepcję zawartą w tomizmie konsekwentnym. Zamiast zakończenia naszkicowane zostaną wybrane problemy w metafizyce człowieka, które w świetle poczynionych ustaleń, odnoście przyczynowania celowego w tomizmie konsekwentnym, domagają się dalszych doprecyzowań i uzupełnień. 


\subsection{Ujęcie Arystotelesa}

Twórcą terminologii związanej z przyczyną celową, jak i pierwszej zwartej koncepcji przyczynowania celowego jest Arystoteles. Wychodząc w swych rozważaniach od rozumienia ruchu, jako przejścia $z$ możności do aktu, podał jego definicję - jako aktualizowanie możności ${ }^{1}$. Akt $w$ tym ujęciu jest tym, co tę możność realizuje, doskonali ${ }^{2}$. Konsekwencja wyprowadzona $\mathrm{z}$ tych twierdzeń jest jednoznacznym stwierdzeniem, że to akt jest celem ruchu, zapodmiotowanego w możności - „akt formujący byt możności jako takiej jest ruchem"' . W konkretnym bycie tym aktem, doskonałością jest forma - „bo celem jest forma, a doskonałym to, co posiada formę"4. I dalej Stagiryta doda: „chodzi tu o przyczynę, a jest nią forma, przez którą materia jest czymś. I to jest substancją"s. Zatem to materia, rozumiana jako możność jest tą zasadą, która zostaje ukazana jako pierwsza - „tym, co pożąda formy jest materia" To z kolei stało się powodem, dla którego Stagiryta nazwie materię przyczyną sprawczą formy, pisząc: „A znowu ów trwający substrat [materia] jest przyczyną sprawczą formy rzeczy powstającej, jak gdyby 'matką"' . Czyli „to co się zmienia jest materią, a to, $w$ co się zmienia jest formą" ${ }^{\prime \prime}$. W bycie złożonym $\mathrm{z}$ formy $\mathrm{i}$ materii, materia jest czynnikiem możnościowym, ale jej możność jest ograniczona przez formę przecież to forma wyznacza możność podmiotowania określonych przypadłości. Będąc aktem, jest jednocześnie celem bytu, ponieważ decyduje ostatecznie jaki ten byt będzie. $\mathrm{Z}$ tego wynika, że ruch w substancji będzie polegał na przejściu z możności do aktu. A dokładniej, wyłonieniu z możności, jako materii, aktu jako formy.

Przyczyną celową $w$ przedstawianym przez nas rozumieniu jest forma, ponieważ przyczyna celowa będąc motywem lub kresem, zawsze dotyczy pewnej zmiany, wyznacza jej kierunek. Jest, w pewnym sensie, przyczyną celową wewnętrzną, będąc wewnątrz bytu?.

1 Arystoteles, Fizyka, w: Dziela wszystkie, t. 2, tłum. K. Leśniak, Warszawa 1990, 65 (ks. III,

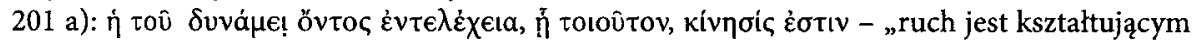
aktem bytu istniejącego w możności o ile jest w możności”. (dalej cytowana jako Fizyka); Por. Arystoteles, Metafizyka, tłum. M. A. Krąpiec, A. Maryniarczyk na podstawie przekładu T. Żeleźnika, t. II, 173 (ks. XI, 1065 b 35-1066 a 5). (dalej cytowana jako Metafizyka).

3 Fizyka, 65 (ks. III, 201 a); Zob. tamże, 67 (ks. III, 201 a-201 b); Por. Metafizyka, t. II, 171 (ks. XI, 1065 b 15).

4 Metafizyka, t. I, 277-287 (ks. V, 1022 a 5-1023 a 35):

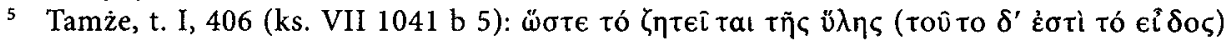
फ़̃ Tí ह̇oเv.

6 Tamże, 44 (ks. l, 192 a).

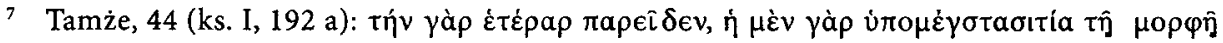

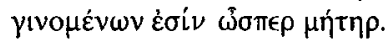

8 Metafizyka, t. II, 201-202 (ks. XII, 1070 a 5).

9 W odniesieniu do Arystotelesa Gilson napisze: „źródło stosunku zachodzącego między skutkiem a przyczyną znajduje się więc właśnie w istocie, a nie gdzie indziej" - E. GILson, Byt $i$ istota, Warszawa 1963, 53-54. 
Jednak idąc dalej, za Arystotelesem, w analizowaniu ruchu zapodmiotowanego w możności w dążeniu do formy, dochodzimy do wniosku, że ruch jest naznaczony celowością. Takie rozumienie wskazuje na przyczynę celową, która powoduje, że ruch ten nie tylko zmierza do swego kresu, ale zmierza do kresu, który jest jego celem. Przyczyną, która to powoduje jest forma, ale nie forma w bycie, gdyż ta powstaje dopiero pod wpływem tego ruchu (jest celem ruchu). Chodzi tu raczej o czystą formę, czysty akt, który jest jednocześnie przyczyną zewnętrzną. Własnie w tym kontekście umieszczone są rozważania Stagiryty dotyczące Pierwszego Nieporuszonego Poruszyciela.

Skoro w Metafizyce Arystoteles stwierdza, mówiąc o Absolucie, że to od niego, jako od przyczyny celowej zależy niebo i cała natura ${ }^{10}$, to konsekwencje przyczynowania celowego muszą być również w bycie przygodnym. Poruszyciel będąc czystą formą oraz czystą doskonałością - jest najwyższym dobrem ${ }^{11}$. Jest celem pożądania, $\mathrm{w}$ ten sposób porusza. Tak rozumiane przyczynowanie jest przyczynowaniem celowym - „porusza on jako pożądany, a inne rzeczy poruszają, o ile są wprawione w ru$\mathrm{ch}^{\text {"12}}$. Poruszyciel będąc ostatecznym przedmiotem dążenia bytów, jest poniekąd ich sprawcą ${ }^{13}$. Czyli poprzez bycie przyczyną celową, jest zarazem przyczyną sprawczą, jednak niejako wtórnie ${ }^{14}$.

Skoro "celem jest forma, a doskonałym to, co posiada formę"15, to wyłanianie się formy z możności materii jest działaniem celowym, wyznaczonym przez przyczynę celową. $Z$ takim rozumieniem przyczynowania celowego spotykamy się zarówno, gdy Arystoteles wyjaśnia ruch ciał niebieskich, wtedy bezpośrednią przyczyną celową jest Pierwszy Nieporuszony Poruszyciel ${ }^{16}$, jak i bytu przygodnego, a wówczas przyczyną

10 Zob. Metafizyka, t. II, 223 (ks. XII, 1072 b 25-1073 a 10).

11 W księdze XII Metafizyki Filozof tak wyjaśnia to zagadnienie: „Otóż w taki sposób porusza to co pożądane i to co intelektualnie poznane: porusza, samo nie będąc poruszane. A pierwsze w obu tych porządkach jest to samo. Pożądane bowiem jest to, co jawi się jako dobro, a chciane jest najpierw dobro rzeczywiste. Pragniemy zaś czegoś raczej, ponieważ jawi się jako dobro, aniżeli przeciwnie, jawi się coś jako dobro, ponieważ tego pragniemy; zasadą - początkiem bowiem jest myśl. Intelekt zaś poruszany jest przez [to co poznawane] jako takie. I pierwsza jest tu substancja, a znowu pierwszą substancją jest substancja prosta jako akt. Ale w tym samym porządku jest również dobro i to, co wzbudza pożądanie samo z siebie, przy czym takie pierwsze jest zawsze najlepsze lub analogiczne z nim" - Metafizyka, t. II, 219-220 (ks. XII 1072 a 25-35).

12 Tamże, t. II, 220 (ks. XII, 1072 b 5).

13 Por. W. Deubacz, Problem Absolutu w filozofii Arystotelesa, Lublin 1992, 169.

14 Por. M. A. KRĄPIEC, Arystotelesowska koncepcja substancji, Lublin 2000, 69. Kilka stron dalej M. A Krapiec dodaje - „jest to ruch pojmowany przez Stagirytę jako akt bytu w możności jako takiej', czyli jest aktualizacją możności (jakiejkolwiek), gdziekolwiek ma ona miejsce [...]. Wobec tego arystotelesowski bóg, jako pierwszy motyw ruchu kosmicznego, przez sam fakt ruchu (bez motywu ruchu - ruch nie zaistnieje), jest obecny wszędzie tam, gdzie jest ruch, pojmowany jako aktualizacja możności [...]. Dobro jest celem i motywem ruchu najszerzej pojętego [...]" - Tamże, 75; 76.

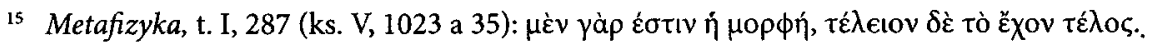

16 Por. Tamże, t. II, 225-227 (ks. XII, 1073 a 20-1073 b 5). 
celową jest byt zewnętrzny, który tak oddziałuje na możność bytu przygodnego, że ta wyłania $z$ siebie akt, który jest celem tego „wewnątrz-bytowego" ruchu ${ }^{17}$. A więc przyczyna celowa tak oddziałuje na ruch zapodmiotowany w możności, że ta wyłania $\mathrm{z}$ siebie akt.

Wskazanie na cztery przyczyny bytu (przyczynę materialną, formalną, sprawczą i celową) pozwoli, zdaniem Stagiryty na pełne ujęcie, zrozumienie rzeczywistości. Jednak już tutaj widać, że wśród przyczyn prymat wiedzie przyczyna celowa, ona uzasadnia działanie pozostałych, ponieważ jest tym, ze względu na co pozostałe działają.

\subsection{Ujęcie Tomasza z Akwinu}

Rozumienie przyczynowania celowego, wydobyte z tekstów Tomasza z Akwinu, jest dwupłaszczyznowe, ponieważ dotyczy z jednej strony rozstrzygnięć filozoficznych (związanych $z$ rozumieniem natury człwoieka), jak i teologicznych (związanych $\mathrm{z}$ rozumieniem łaski, a także $\mathrm{z}$ celem ostatecznym człowieka, którym jest ogladanie istoty Bożej) ${ }^{18}$. W przypadku natury i szczęśliwości, jako celu ostatecznego, mamy do czynienia z problematyką władz człowieka (intelektu i woli) jako zasad działania. Gdy problem ten rozważany zostanie w perspektywie skłonności do doskonałości ${ }^{19}$, to po pierwsze - analiza tych skłonności wskaże na ujęcie bytu z perspektywy jego stworzenia. Po drugie - skłonność stanie się widoczna w Tomaszowej koncepcji rządów Bożych, rozumianych jako naśladowanie skutku przez przyczynę ${ }^{20}$.

O tym, że Bóg jest przyczną sprawczą dowiadujemy się już w tzw. drugiej drodze, jednak występujące tam przyczyny wtóre są również zaliczone do przyczyn sprawczych ${ }^{21}$. Natomiast o tym, że Bóg jest także przyczyną celową dowiadujemy się zawsze na

17 Zob. Tamże, t. II, 213-214 (ks. XII, 1071 b 10-20); Por. tamże, t. II, 218-219 (ks. XII, 1072 a 20 -35); Zob. Fizyka, 188 (ks. VIII, 260 a); Tamże, 184-185 (ks. VIII, 258 b-259 a). Na temat dowodzenia Arystotelesa dotyczącego pierwszych poruszycieli zob. W. Dłubacz, dz.cyt.,135-153; Por. M. Gogacz, Platonizm i arystotelizm, Warszawa 1996, 59.

18 Zob. E. Gilson, Tomizm, tłum. J. Rybałt, Warszawa 1998, 16; 36; 107; 434.

19 Nașzym zdaniem można ten problem rozważyć stosując do niego doktrynę aktu (tak rozumiana jest doskonałość) i możności (tak rozumiana jest skłonność).

20 Obydwa te aspekty wynikają z posługiwania się przez Tomasza zarówno dowodzeniem quia, jak i propter quid. O różnicy między dowodzeniem quia i propter quid zob. Summa Theologiae, I, q. 2, a. 2c. (dalej cytowana jako ST); Por. T. STĘPIEŃ, Problematyka filozoficzna Traktatu o aniolach św. Tomasza z Akwinu (ST I, q. 50-64), maszynopis, 21.

${ }_{21}$ Zob. ST I, q. 2, 3c; Por. De substantiis separatis, 10, tl. J. Salij, w: Tomasz z Akwinu, Dzieła wybrane, Poznań 1984, 317-319; Tamże, 16, 327-328. Problem ten został niedawno poruszony przez T. Stępnia w artykule Problem przyczynowania sprawczego w ujęciu Mieczystawa Gogacza w kontekście „drugiej drogi” 'św. Tomasza z Akwinu, który ukazal się w Studia Philosophiae Christianae 42 (2006) 2, 95-108; Podobnie W Summie contra Gentiles czytamy: „usunąwszy zaś przyczynę, usuwa się to, czego jest ona przyczyną. Gdy się zatem usunie pierwszą, pośrednia przyczyna (medium causa) nie będzie mogła być przyczyną. Lecz gdyby w przyczynach sprawczych (causis efficientibus) postępować w nieskończoność, wówczas żadna z przyczyn nie będzie pierwsza. Usuwa się zatem wszystkie, które są pośrednie. Jest to oczywiście fałszywe. Zatem należy przyjąć, że istnieje pierwsza przyczyna sprawcza (primam causam efficientem). A tą jest Bóg" - Summa contra Gentiles I, cap. 13 (dalej cytowana jako SCG); Por. De substantiis separatis, 9, s. 315. 
kanwie rozważań teologicznych. Przyczynowanie celowe zawsze dotyczyć będzie w pierwszej kolejności samego aktu stwórczego Boga, a następnie poznania i dążenia do Niego, przez byt przygodny, jako do celu ostatecznego ${ }^{22}$. Skoro ostatecznym dobrem jest Bóg, to Bóg jest przyczyną celową, ponieważ jest pierwszą przyczyną i celem ostatecznym każdej rzeczy ${ }^{23}$.

Dążenie bytu do Boga ma dwa wymiary. $Z$ jednej strony chodzi tu o usprawnianie władz, a $z$ drugiej o bycie przyczyną dla innych rzeczy $^{24}$. $Z$ tego wynika, że istota bytu w działaniu (natura), poprzez wszystkie swe władze jest ową skłonnością „naznaczona”, skoro została stworzona ${ }^{25}$. A aktualizowanie owych skłonności jest doskonałością bytu.

Akwinata naturę definiuje jako ,istotę rzeczy ujętą ze względu na to, że jest przyporządkowana do właściwych bytowi działań" ${ }^{\prime 26}$. Właściwym działaniem bytu ludzkiego jest poznawanie, które jest doskonałością ${ }^{27}$. Chodzi tutaj o poznanie prawdy, które jest doskonałością intelektu, a tym samym jego dobrem; oraz o dążenie woli do celu, również jako dobra, które jest jej doskonałością ${ }^{28}$. To $\mathrm{z}$ kolei jest powodem powiązania przez Tomasza problematyki sprawności intelektu i woli jako przysposobienia do działania (dążenia do celu ostatecznego) jako celu natury ${ }^{29}$. Czyli wynika z natury bytu, że poznaje i pożąda on celu ostatecznego - „ostatecznym więc celem całego człowieka i wszystkich jego działań i pragnień jest poznanie pierwszej prawdy,

22 Zob. SCG III, cap. 25.

23 Zob. SCG III, cap. 17; Por ST I q. 13 a. 2c. O utożsamieniu sprawcy i celu Tomasz pisze: „ponieważ tym samym jest pierwsza zasada rzeczy i cel ostateczny, dlatego w ten sam sposób rzeczy pochodzą od pierwszej zasady i w ten sam sposób odnoszą się do celu ostatecznego". - Quaestiones disputatae de veritate, q. 5, a. 4c. (dalej cytowana jako DV); Zob. Tamże, q. 21, a. 5 c.

24 "rzeczy są skierowane (ordinantur) do Boga jako do celu nie tylko według bytu substancjalnego (esse substantiale), lecz także według tego wszystkiego, co dla tego bytu jest przypadłościowe (accidunt), a należy do jego doskonałości, a także według wlaściwego im działania, które także należy do doskonałości rzeczy". - SCG III, cap. 20.

25 SCG III, cap. 21. Nieco dalej Tomasz wyjaśniając to zagadnienie na przykładzie doskonałości gatunku - rodzenia, doda: „rodzący bowiem dąży do formy zrodzonego; a jednak zrodzone nie jest bardziej godne (dignius) od rodzącego, lecz w czynnikach jednoznacznych należą oba do tego samego gatunku. Rodzący nie zmierza bowiem jako do celu ostatecznego, do formy zrodzonego, która jest celem rodzenia; lecz do podobieństwa do bytowania (esse) Bożego w utrwaleniu gatunku, i w udzielaniu swej dobroci przez to, że przekazuje innym formę swojego gatun$\mathrm{ku}$, i jest przyczyną innych rzeczy" - SCG III, cap. 22.

${ }_{26}$ Natura est essentia rei secundum quod habet ordinem ad propriam operationem rei. De ente et essentia, 4; Por. $z$ definicją natury z ST I, q. 76, a. 1c

27 „wszystko co istnieje ze względu na jakiś cel, jest określone na miarę tego celu, do którego jest przyporządkowane (ordinatum)" - DV, q. 15, a. 2c.

${ }_{28}$ Zob. DV, q. 15, a. 2c; Por. ST I, q. 5, a. 1c; Por. definicję dobra z ST I-II q. 1,a. 1c: [..] Bonum et finis est obiectum voluntatis [...].

29 Zob. ST I-II, q. 49, a. 3c; Por. ST I-II, q. 49, a. 4, ad 3; Zob. ST I-II, q. 50, a. 5, ad 1; Sprawności woli potrzebne są by kierowała się do tego przedmiotu, który ukazuje jej intelekt - Zob. Tamże, q. 51, a. 1c. 
którą jest Bóg"30. Nabycie sprawności jest doskonałością bytu ${ }^{31}$. Z tego wynika, że problematyka usprawniania intelektu i woli jest kluczowa w rozumieniu przyczynowania celowego jako dążenia bytu przygodnego do celu ostatecznego $\mathrm{w}$ aspekcie doskonałości.

Kolejnym aspektem tak rozumianego przyczynowania celowego jest problematyka związana $z$ przyczynami wtórymi ${ }^{32}$. Po pierwsze, to one odpowiadają za kształtowanie się istoty bytu - "natomiast inne przyczyny nie są przyczyną istnienia (causa essendi) wprost, lecz przyczyną bycia czymś (causa essendi hoc), jak na przykład człowiekiem lub czymś białym" ${ }^{33}$. Drugim tropem jest wskazanie przez Akwinatę na podobieństwo skutku (bytu przygodnego) do swojej przyczyny. Chodzi tu o podobieństwo co do bytowania i działania przez przyczyny wtóre ${ }^{34}$. Przyczyny wtóre to również te przyczyny, które mogą zachowywać niektóre rzeczy w istnieniu ${ }^{35}$. Analizując porządek przyczyn sprawczych Akwinata doda: „jedna czynność nie pochodzi od dwóch przyczyn sprawczych jednego porządku. Nic jednak nie przeszkadza, żeby jedna i ta sama czynność pochodziła na raz od pierwszej i drugiej przyczyny sprawczej”36. $\mathrm{Z}$ tego wynika, że przyczyny wtóre współdziałają z Bogiem w aspekcie przyczynowania sprawczego i celowego.

W tym momencie rozważań wręcz narzuca się prześledzenie Tomaszowej koncepcji Bożych rządów. „Kluczem” do zrozumienia tego zagadnienia jest ponownie udzielanie doskonałości, które jest konsekwencją przyczynowania celowego ${ }^{37}$. Akwinata pisze: „wielkość Bożej opatrzności i Jego dobra bardziej objawia się w tym, że bytami niższymi kieruje poprzez wyższe, niż gdyby wszystkimi kierował bezpośrednio, gdyż w tej sytuacji, jak powiedziano, doskonałość Bożego dobra udziela się

\footnotetext{
SCG III, cap. 25.

Zob. DV, q. 1, a. 10, ad 3.

Zob. SCG I, cap. 67; Por. DV, q. 2, a. 14, ad 5.

33 SCG II, cap. 21. Dalej Tomasz sprecyzuje, że przyczynowość przyczyn wtórych jest inna niż przyczynowość stwórcza: Esse autem simpliciter per creationem causatur, quae nihil praesupponit: quia non potest aliquid praeexistere quod sit extra ens simpliciter. Per alias factiones fit hoc ens vel tale: nam ex ente praeexistente fit hoc ens vel tale. Ergo creatio est propria Dei actio [...] - Tamże.

34 „Nie jest tez zbytecznym, jeśli Bóg sam przez się może powodować wszystkie skutki naturalne, by i pewne i inne przyczyny je powodowały. Nie pochodzi to bowiem z niedostateczności mocy Bożej, lecz z niezmierzoności Jego dobroci, dla której chciał udzielić rzeczom Swego podobieństwa, nie tylko odnośnie bytowania (essent), lecz także odnośnie do tego, by się stawały przyczyną innych rzeczy; tymi bowiem dwoma sposobami dostępują wszystkie stworzenia wspólnie podobieństwa Bożego, jak to powyżej wykazano. W ten sposób ukazuje się także piękno porządku. w rzeczach stworzonych" - SCG III, cap. 70; Por. DV, q. 11, a. 1c.

35 Zob. ST I, q. 104, a. 2c: Sic igitur dicendum est quod Deus conservat res quasdam in esse, mediantibus aliquibus causis.

36 Tamże, I, q. 105, a. 5, ad 2.

37 Zob. Tamże, I, q. 103, a. 6c. Bóg działa przy pomocy przyczyn wtórych ze względu na adekwatność powodowanych skutków - Zob. DV, q. 27, a. 4, ad 16.
} 
większej ilości stworzeń" ${ }^{38}$. Boska Opatrzność, rozumiana jako Boża pomoc w owym dążeniu, to wszystkie "pomoce" nadawane stworzeniu w porządku laski. Cel ostateczny nie jest możliwy do osiągnięcia wysiłkami wynikającymi $z$ natury bytu, musi ona zostać uzupełniona, czyli udoskonalona w porządku łaski. Tomasz pisze: „to co porusza, jako przyczyna pośrednicząca, może poruszać tylko wtedy, gdy istnieje coś, co porusza jako przyczyna główna" ${ }^{39}$. Samo zaś sprawowanie rządów nad światem Akwinata ujmuje w trzech aspektach. „Skutek każdej czynności można ocenić badając jej cel, gdyż właśnie działanie sprawia, że się osiąga cel. Celem zaś rządów nad światem jest dobro istotowe (bonum essentiale) i do uczestniczenia w nim tudzież do upodobnienia się do niego dążą wszystkie rzeczy. A więc skutek rządzenia można ujmować trojako. Po pierwsze od strony samego celu: $i$ tak istnieje tylko jeden skutek rządów, mianowicie upodobnienie się do najwyższego dobra. Po drugie, od strony środków, którymi stworzenie jest doprowadzone do upodobnienia się do Boga.[...] Po trzecie, skutek rządzenia można ujmować od strony poszczególnych wypadków: i tak są one nieprzeliczone"40. $Z$ dobroci Bożej, z Jego doskonałości wynika, że przyczyny wtóre mogą uczestniczyć w rządach Bożych. Jest to niewątpliwie pewna doskonałość skutku, która sprawia, że upodabnia się on do swojej przyczyny ${ }^{41}$.

Warto w tym miejscu zastanowić się nad charakterem, mocą przyczyn wtórych i ich zależnością bądź samodzielnością w przyczynowaniu. Tomasz stwierdza, że przycznowanie zależne jest od mocy. Im przyczyna ma większą moc, tym jej przyczynowanie (zarówno sprawcze jak i celowe) jest doskonalsze, obejmuje więcej rzeczy ${ }^{42}$.

38 DV, q. 5, a. 8, ad 11; Por. ST I, q. 15, a. 2c. Omawiane zagadnienia można także ująć w ramach tzw. pierwotnej miłości utożsamiając ją ze skłonnością np. woli do dobra i intelektu do prawdy. Na ten temat zob. M. A. KRĄPIEC, Struktura aktu miłości u św. Tomasza z Akwinu, Roczniki teologiczno - kanoniczne, 6(1960), z. 1-2, 135-154; Por. ST I-II, q. 4, a. 3c.

Problem ten poruszył już Etienne Gilson, który w Tomizmie jednoznacznie stwierdza, że tak rozumiana opatrzność jest przyczynowością - Zob. E. Gilson, Tomizm, dz. cyt., 173; Por. ST I, q. 22, a. $13 \mathrm{c}$.

39 SCG I, cap. 13: [...] id quod movet instrumentaliter, non potest movere nisi sit aliquid quod principaliter moveat [...].

40 ST I, q. 103 , a. $4 c$.

41 ST I, q. 103, a. 6c: [...] cum Deus sit ipsa essentia bonitatis, unumquodque attribuendum est Deo secundum sui optimum. Optimum autem in omni genere vel ratione vel cognitione practica, qualis est ratio gubernationis, in hoc consistit, quod particularia cognoscantur, in quibus est actus [...]. Unde oportet dicere quod Deus omnium etiam minimorum particularium rationem gubernationis habeat. Sed cum per gubernationem res quae gubernantur sint ad perfectionem perducendae; tanto erit melior gubernatio, quanto maior perfectio a gubernante rebus gubernatis communicatur. Maior autem perfectio est quod aliquid in se sit bonum, et etiam sit aliis causa bonitatis, quam si esset solummodo in se bonum. Et ideo sic Deus gubernat res, ut quasdam aliarum in gubernando causas instituat, sicut si aliquis magister discipulos suos non solum scientes faceret, sed etiam aliorum doctores [...].

42 SCG I, cap. 75: [...] Quanto aliquid est perfectioris virtutis, tanto sua causalitas ad plura se extendit et in magis remotum, ut supra dictum est. Causalitas autem finis in hoc consistit quod propter ipsum alia desiderantur. Quanto igitur finis est perfectior et magis volitus, tanto voluntas volentis finem ad plura extenditur ratione finis illius. Divina autem essentia est perfectissima in ratione 
Moc Boża, jako moc celu ostatecznego pociąga wszystko ku sobie. To dzięki niej możemy powiedzieć, że wszystkie działania np. człowieka powinny być skierowane ku temu celowi, także realizowane cele partykularne. Tomasz pisze: „moc zaś celu bierze się nie tylko stąd, że się go pragnie samego przez się, lecz także dlatego, że z powodu niego inne rzeczy stają się pożądane"43.

Tomasz wiąże także posiadanie mocy $z$ działaniami wynikającymi z natury bytu. Zasadą działań w człowieku są jego władze. Przypomnijmy, że jeden skutek może powodować wiele przyczyn, np. przyczyna przygodna (wtóra) i konieczna (Bóg). Tomasz mówi bowiem, że przyczyna wtóra i Bóg przyczynują jeden skutek, ale na różny sposób - „w każdym działającym należy bowiem rozważyć dwie rzeczy, mianowicie samą rzecz, która działa, oraz moc, przez która działa; tak np. ogień ogrzewa przez ciepło. Moc zaś niższego czynnika zależy od mocy czynnika wyższego, jako że czynnik wyższy daje czynnikowi niższemu tę moc, przez którą on działa; [...] Musi więc działanie niższego czynnika nie tylko pochodzić od niego z jego własnej mocy, ale także z mocy wszystkich wyższych czynników; działa on bowiem przez moc wszystkich. [...]. Jak więc nie jest nieodpowiednie, by jedno działanie powstawało od jednego czynnika i od jego mocy, tak też nie jest nieodpowiednie, by jeden i ten sam skutek pochodził od czynnika niższego i od Boga i od obu bezpośrednio choć różnym sposobem"44. Innymi słowy możemy mówić o dwóch aspektach rozważanej przez nas mocy. Pierwszym jest moc uzależniona (dana, stworzona przez Boga) od Pierwszej Przyczyny. Drugi aspekt to moc wynikająca $\mathrm{z}$ natury bytu, którą możemy określić jako konsekwencję przygodności (byt stworzony ma moc działania, właśnie dlatego, że został stworzony). To z działania wnioskujemy o naturze bytu i jego mocy. $\mathrm{Z}$ tego wynika, że jaka jest natura bytu, taka jest moc tego bytu $u^{45}$.

Podsumowując powyższe zależności możemy powiedzieć, że przyczyna sprawia skutek podobny do siebie. Dotyczy to zarówno wewnętrznych pryncypiów, jak i dzialania skutku. Z tego zaś wynika, że przyczynowanie Boga nie kończy się na sprawczości, stworzeniu, lecz także trwa ono niejako pod postacią przyczynowania celowego nad bytem stworzonym. Mówimy wtedy zarówno o Opatrzności Bożej, która wyznacza pewien porządek między przyczynami wtórymi, jak i o dążeniu bytu stworzonego w upodobnieniu się do swojej przyczyny, czyli w aspekcie doskonałości - byciu przyczyną lub doskonaleniu władz.

bonitatis et finis. Igitur diffundet suam causalitatem maxime ad multa, ut propter ipsam multa sint volita; et praecipue a Deo, qui eam secundum totam suam virtutem perfecte vult [...].

43 SCG I, cap. 76 : [...]Finis autem virtus est non solum secundum quod in se desideratur, sed etiam secundum quod alia fiunt appetibilia propter ipsum [...].

44 SCG III, cap. 70.

45 „Doskonałe poznanie jakiejś rzeczy można mieć tylko wtedy, gdy się poznaje jej działanie. Ze sposobu bowiem i gatunku działania ocenia się miarę i jakość jego mocy. Moc zaś ukazuje naturę rzeczy (virtus vero naturam rei monstrat), gdyż każda rzecz zdolna jest działać zgodnie z naturą, jaka w rzeczywistości przypada jej w udziale" - SCG II, cap 1. 


\section{Propozycja M. Gogacza}

W tomizmie konsekwentnym Bóg, jako Samoistny Akt Istnienia, jest przyczyną sprawczą istnienia przygodnego. Natomiast przyczyny celowe kształtują (aktualizują) możność stworzonego istnienia, odpowiadając tym samym, za zawartość treściową istoty. Tym samym możliwe stało się wskazanie bezpośrednich konsekwencji przyczynowania celowego w strukturze bytu, co z kolei zaowocowało bardziej precyzyjnym rozumieniem istoty bytu, pozwoliło także doprecyzować i odróżnić przyczynowanie sprawcze Boga od przyczynowania celowego.

M. Gogacz analizując byt realnie istniejący wyodrębnił dwa rodzaje ujęć - ujęcie strukturalne ${ }^{46} \mathrm{i}$ ujęcie genetyczne ${ }^{47}$. Pokazując różnice między tymi ujęciami wykrył przyczyny celowe.

Ujęcie strukturalne bytu, to wskazanie, że każdy byt przygodny jest istnieniem $i$ istotą. Istnienie odpowiada za to, że byt jest realny. Jest wewnętrzną zasadą, która czyni realnymi pryncypia wewnętrzne, należące do istoty. Natomiast istota jest, względem aktu istnienia, możnością. Dodajmy, że istoty bytów są wewnętrznie zróżnicowane - stanowi je akt i możność, jako forma i materia. M. Gogacz wyróżnia dwa rodzaje możności: duchową i materialną. Ze względu na to zróżnicowanie Tomista mówi o różnych „typach" istoty ${ }^{48}$.

Wskazanie na przyczyny zewnętrzne zidentyfikowanych pryncypiów wewnętrznych nosi nazwę ujęcia genetycznego. Ten rodzaj identyfikacji rozpoczyna się od aktu istnienia, dzięki któremu istota jest realna. Istota jako możność jest niejako wyłoniona $\mathrm{z}$ aktu istnienia. Akt istnienia urealnia formę $\mathrm{w}$ istocie, odpowiadającą za określoność bytu. Natomiast forma udziela określoności podłożu przypadłości, czyli możności ${ }^{49}$. Stworzony akt istnienia wiąże wszystkie pryncypia ze sobą udzielając im jedności, realności i odrębności. W terminologii M. Gogacza, akt istnienia urealnia ${ }^{50}$

46 Zob. M. GogACz, Elementarz metafizyki, Warszawa 1998, 134. (dalej cytowany jako Elementarz metafizyki)

47 Por. tamże, 117

48 Por. Elementarz metafizyki, 29-30. Precyzując takie ujęcie bytu, M. GogACz doda: „Ujęty strukturalnie byt jest więc istnieniem $\mathrm{i}$ istotą. Istoty są zawsze formą i jakąś odmianą możności. Istnienie w tym bycie przejawia się poprzez własności transcendentalne. Istota podmiotuje przypadłości proporcjonalne do współstanowiącej ją z formą możności, która jest albo duchowa albo materialna. W danej istocie może być zaktualizowana możność zarówno duchowa, jak i materialna" - Tamże, s. 30. Władze duchowe i poznanie intelektualne, oraz oparte na nich późniejsze decyzje wskazują na swój podmiot, którym jest możność duchowa (intelektualna). Natomiast ciałem bytu jest zespól przypadłości podmiotowanych przez możność materialną - Zob. tamże, 73-74.

49 Por. Tamże, 31.

so Zob. tamże, 32: „Urealnianie więc bytu przez akt istnienia polega na zapoczątkowaniu tego bytu, urzeczywistnieniu go. Urzeczywistnienie lub urealnienie jest zachowaniem się istnienia wobec innych stanowiących byt pryncypiów. To zachowanie się aktu istnienia ma się tak do niego, jak czynność do swego podmiotu". 
i aktualizuje ${ }^{51}$ istotę, nie jest więc przyczyną sprawczą wewnętrznych pryncypiów istoty $^{52}$. Tomista ten nie kończy identyfikacji wskazując na istnienie, jako akt, i na istotę, jako możność, lecz ukazuje ich przyczyny zewnętrzne ${ }^{53}$. Przyczyną istnienia stworzonego jest Samoistny Akt Istnienia - Bóg, będący przyczyną sprawczą ${ }^{54}$. Przyczynami istoty są przyczyny celowe.

Ważnym zagadnieniem, naprowadzającym na problematykę przyczyn celowych, jest rozumienie natury bytu. M. Gogacz naturę określa jako „istotę ze względu na jej powiązania $z$ odpowiednimi dla niej, oddziałującymi na nią otaczającymi ją bytami. Natura więc to istota wzbogacona skutkami oddziałujących na nią bytów"55. Sprecyzujmy, za omawianym autorem, że oddziaływanie bytu zewnętrznego na powstającą istotę, nie ma charakteru sprawczego - „zewnętrzne pryncypia istoty mogą być tylko wzorem, modelem istoty, jej miarą o charakterze celu. Nazywa się je właśnie przyczynami celowymi. Znaczy to, że są dla istoty obrazem tego, czym ma być ta istota" ${ }^{\text {"56 }}$. To oddziaływanie polega na tym, że możność powstającego bytu aktualizuje się na miarę wyznaczoną przez istotę przyczyny celowej. Jednak, gdy M. Gogacz rozważa istotę czlowieka jako duszę i ciało, to stwierdza, że inna przyczyna celowa jest odpowiedzialna za kształtowanie się duszy, a inna za kształtowanie się ciała.

51 Zob. tamże, 32: „Aktualizowanie to takie zachowanie się aktu istnienia, że wszystko, co w bycie urealnione, wiąże on ze sobą. Dzięki ogarnięciu przez akt istnienia wszystkiego, co w bycie zaktualizowane, byt staje się strukturalną jednością. Ta jedność przejawia w bycie istnienie i jego dominującą rolę pierwszego aktu bytu".

Zob. M. GogACZ, Akt istnienia (ipsum esse) wedlug tomizmu konsekwentnego, Studia Philosophiae Christianae 22 (1986) 2, 31-32.

52 Zob. tamże, 34.

53 „Ponieważ $w$ bycie obok istoty $i$ istnienia nie ma innych podstawowych pryncypiów, to powodem tego, że akt istnienia jest $w$ bycie i urealnia istotę, musi być pryncypium zewnętrzne wobec bytu, ukonstytuowanego $\mathrm{z}$ istnienia i istoty" - Elementarz metafizyki, 33.

Autor stwierdzi wprost, że „akt istnienia dopuszcza wpływ przyczyn celowych i na ich miarę powoduje komponowanie się istoty $\mathrm{w}$ formę i materię [...]. Przyczyny zewnętrzne wyjaśniają genezę aktu istnienia (przyczyna sprawcza) i naturę istoty (przyczyny celowe)". - M. GoGACz, Akt istnienia (ipsum esse) wedlug tomizmu konsekwentnego, art. cyt., 30.

54 Tamże, 35. M. Gogacz zwraca w tym miejscu uwagę, podczas prowadzenia przez siebie identyfikacji przyczyn, że skoro wyodrębnil różne „typy” istoty, to akt istnienia jest czynnikiem, który zezwala na działanie określonych dla powstania bytu (jemu koniecznych) przyczyn celowych. $\mathrm{Z}$ kolei na tej podstawie, omawiany autor, dokonuje identyfikacji różnych typów aktu istnienia. Są to: samoistny akt istnienia, akt istnienia bytów osobowych $i$ akt istnienia przypadłości.

55 Tamże, 13. Dodajmy już w tym miejscu, że każde spotkanie bytów, rozumiane jako łącząca je więź, zależne jest od ich natury. Dlatego na przykład obecność, jako relacja łącząca dwa byty osobowe, jest wyznaczona przez naturę tych bytów, tylko byty osobowe mogą być powiązane relacjami osobowymi, które oparte są na własnościach transcendentalnych.

Por. P. Milcarek, Teoria ciała ludzkiego w pismach św. Tomasza z Akwinu, Warszawa, 192: „Dlatego w ujęciu genetycznym przez naturę rozumie się istotę przyjmującą przyczynowe oddziaływanie bytów otaczających".

56 Elementarz metafizyki, 34. Omawiany autor wyjaśnia, że czym innym jest cel bytu, a czym innym jego przyczyna celowa. O ich nietożsamości zob. M. GoGACz, Człowiek i jego relacje (materiały do filozofii czlowieka), Warszawa 1985, 11. 
Przyczyna duszy, skoro oddziałuje tym, czym sama jest, musi być substancją duchową ${ }^{57}$. Zatem dusza uprzyczynowana swoje „zmożnościowanie” zawdzięcza wpływowi przyczyn celowych. Skoro struktura duszy to forma i możność duchowa, urealniona przez akt istnienia, to jej przyczyna jest zbudowana $z$ wewnętrznego aktu istnienia, którego przyczyną sprawczą jest Istnienie Samoistne. Natomiast w swej istocie jest formą i możnością duchową. M. Gogacz wskazuje, że różnica między duszą ludzką, a jej przyczyną celową tkwi w skierowaniu formy. U przyczyn celowych to skierowanie jest ku aktowi istnienia, a u człowieka ku ciału ${ }^{58}$. Kolejną różnicą jest inaczej ujęte jednostkowienie formy. $U$ przyczyn celowych forma jest jednostkowiona przez intelekt możnościowy, a u człowieka przez intelekt możnościowy i możność materialną. Różny też jest typ aktu istnienia u przyczyn celowych i u człowieka ${ }^{59}$. Tak ujęte przyczyny celowe nazwane zostały - zgodnie $\mathrm{z}$ tradycją - aniołami.

Analogicznie jest $\mathrm{z}$ ciałem człowieka, którego koniecznymi przyczynami celowymi są „najprostsze struktury materialne i kody genetyczne rodziców"60. Byty o istocie duchowo - cielesnej (np. rodzice) są także przyczynami celowymi powstającej istoty człowieka. Oddziałują duchowo - cielesną istotą jako przyczyny celowe zarówno ciała, jak i psychiki' ${ }^{11}$. Przyczyn celowych psychiki człowieka jest więcej, można powiedzieć, za omawianym autorem, że są to wszyscy ludzie, z którymi jest on powiązany relacjami, a którzy jednocześnie wpływają na kształtowanie się jego przeżyć, uczuć itd ${ }^{62}$.

57 Por. Elementarz metafizyki, 34; Por. tamże, 19-21; 40; Zob. M. Gogacz, Akt istnienia (ipsum esse) wedlug tomizmu konsekwentnego, art. cyt., 33. M. GoGACZ sprecyzuje, że przyczyny celowe duszy jako byty, są samodzielne, lecz nie samoistne - „identyfikując wśród bytów te, które z racji spełnianego działania są przyczynami, odróżniamy więc przyczynę sprawczą zewnętrzną wobec istnienia powiązanego $w$ danym bycie $z$ istotą oraz odróżniamy przyczynę celową zewnętrzną powodującą tożsamość istoty. [...] Przyczyny celowe to samodzielne, lecz nie samoistne byty, które razem z samoistną przyczyną sprawczą współsprawiają byt uprzyczynowany, czyli przygodny. Nigdy przyczyną celową nie może być byt samoistny, tymi przyczynami celowymi są więc byty przygodne. [...] Natomiast przyczyną celową jest byt przygodny, współpracujący z samoistną przyczyną sprawczą nad ukonstytuowaniem się w spójną jedność tych przyczyn wewnętrznych, które stanowią ten oto, odrębny byt przygodny" - M. GoGACz, Czlowiek i jego relacje, dz. cyt., 21.

58 Jest to problem commensuratio i intelektu kommensurującego, rozwinięcie tego zagadnienia zostanie podjęte w zakończeniu.

59 Por. M. Gogacz, Czlowiek i jego relacje, dz. cyt., 43-45.; Por. M. GogaCz, Filozoficzna konieczność istnienia aniołów jako celowych przyczyn dusz ludzkich, w: Człowiek we wspólnocie Kościoła, Warszawa 1979, 113.

60 „to stworzone istnienie aktualizuje duszę, jako formę, która z kolei aktualizuje w sobie materię, ogarnia przekazane przez rodziców tworzywa fizyczne i umożliwia duszy komponowanie z nich własności fizycznych w taki sposób, że wywolana formą obecna w niej materia, podmiotuje w sobie te własności i przyczynuje ich powiązanie ze sobą" - Elementarz metafizyki, 38.

61 Por. Elementarz metafizyki, 35.

62 M. Gogacz doda, że „ludzie, swoim człowieczeństwem [...] mogą pełnić rolę przyczyn celowych o wiele skuteczniej wtedy, gdy powiąże ich z człowiekiem przyjaźń lub miłość" - M. GogACz, Czlowiek i jego relacje, dz. cyt., 45; Por. podział przyczyn celowych dokonany przez omawianego autora w: M. GoGACz, Człowiek i jego relacje, dz. cyt., 50. 
Ciekawą sugestią jest myśl M. Gogacza zawarta w książce Człowiek i jego relacje. Czytamy tam: „to, czego bezpośrednim podmiotem jest istota duszy ludzkiej, jej działania, muszą w istotowej warstwie kształtować i chronić aniołowie. Samą też istotę duszy muszą - po jej powstaniu - podtrzymywać w jej bytowej kompozycji, gdyż brak tego podtrzymującego $w$ trwaniu przyczynowania celowego dałby w wyniku izolację istoty duszy. Brak stałego wyznaczania przez przyczyny celowe kierunku konstytuowania się istoty duszy w rozumny byt samodzielny mógłby spowodować - przy jej izolacji - zmianę tego kierunku, co stałoby się przyczyną jej właśnie istotowej zmiany, równającej się zniszczeniu duszy" ${ }^{63}$. Z tego wynika, że przyczynowanie celowe trwa tak długo jak istnieje byt. Dusza ludzka jest nieśmiertelna, więc tak rozumiane przyczynowanie, jako „relacja” kształtująca i chroniąca, trwa nieustannie.

Podsumujmy dotychczasowe rozważania. Przyczyny celowe, $w$ tomizmie konsekwentnym, decydują o tym, jaka będzie w swej strukturze istota bytu. Arystotelesowskie i Tomaszowe ujęcie przyczynowania celowego jest niewątpliwie inne. Jest tak dlatego, że inne jest rozumienie struktury bytu. Inne są również punkty wyjścia. Choć na "pierwszy rzut oka” wydawać by się mogło, że wszystkie przedstawione przez nas koncepcje nie mają wielu punktów wspólnych, to jednak zbyt dużym uproszczeniem byłoby stwierdzenie, że to jedynie terminologia używana jest ta sama u wszystkich filozofów. Rzeczywiście $M$. Gogacz korzysta z pojęć ukutych przez Arystotelesa, ale nadaje im odmienne znaczenie, niż pierwotnie mają one u Stagiryty. I właśnie to zmienione znaczenie jest kluczem do poprawnego zrozumienia tej koncepcji w tomizmie konsekwentnym. M. Gogacz zaczerpnął to odmienne znaczenie od św. Tomasza. Sam Akwinata w płaszczyźnie filozoficznej przyczynowanie celowe rozumie podobnie jak Arystoteles, ale gdy filozoficznie wyjaśnia teologiczną koncepcję szczęśliwości wiecznej jako celu ostatecznego, to wielokrotnie umieszcza $\mathrm{w}$ tej perspektywie przyczynowanie przez przyczyny wtóre. Paradoksalnie właśnie to powiązanie przyczynowania celowego z przyczynowaniem wtórym stało się źródłem dla nowej formuły, zarówno samego rozumienia przyczyny celowej, jak i skutków jej działania, w tomizmie konsekwentnym. Już Arystotelesowskie wyłanianie się formy $z$ możności materii, jest konsekwencją przyczynowania celowego, $w$ aspekcie doskonałości. Natomiast skłonności bytu przygodnego, będące konsekwencją stworzenia, są również elementem przyczynowania celowego u Tomasza, rozumianego jako powrót bytu do Boga. Czyli również jest to aspekt związany z doskonałością bytu. $Z$ kolei bycie przyczyną, a zatem cała problematyka przyczynowości wtórej, jest doskonałością nadaną przez Boga stworzeniu. To właśnie to nadanie tej doskonałości dokonuje się w kontekście przyczynowania celowego u Akwinaty. Przyczyny celowe $\mathrm{w}$ tomizmie konsekwentnym odpowiadają za kształtowanie istoty bytu powstającego, są celem (modelem, wzorem) tej istoty. Ponad to są bytami samodzielnymi. W takim

63 Tamże, 44. 
ujęciu Tomaszowa skłonność do doskonałości jest niczym innym jak tylko powstawaniem istoty. Na zakończenie zwróćmy jeszcze uwagę, że przyczynowanie celowe, tak jak ujmuje je M. Gogacz, jest najpełniejszą jego formą, ma ono jednak swoją bogatą $\mathrm{w}$ rozumienia historię filozoficzną.

\section{Zamiast zakończenia}

Uzupełniając wcześniejsze analizy można pokazać dwa zagadnienia, mieszczące się w problematyce przyczynowania celowego w tomizmie konsekwentnym, wymagające dalszych doprecyzowań. Pierwszym jest zależność między przycznowaniem celowym a commensuratio animae ad hoc corpus, a drugim istotowa strona relacji osobowych a przyczynowanie celowe.

Zagadnienie commensuratio napotykamy, gdy M. Gogacz tłumaczy związek duszy z ciałem w człowieku, oraz gdy wykazuje jednostkowość duszy ${ }^{64}$. Problem commensuratio składa się z dwóch zagadnień. Są to: problem jednostkowienia duszy przez intelekt możnościowy i uszczegółowienia duszy przez materię, oraz wskazanie na adekwatną przyczynę commensuratio.

M. Gogacz wykluczając możliwość stania się duszy, po śmierci ciała, gatunkowym absolutem, twierdzi, że duszę musi jednostkować intelekt możnościowy, jako właściwa możność duszy, a nie ciało, które ona traci w momencie śmierci ${ }^{65}$. Wynika to także $\mathrm{z}$ rozumienia aktu i możności - czynnik jednostkujący musi być w tym ujęciu możnością.

Działaniem typowym dla duszy ludzkiej jest poznanie, które jest zapodmiotowane w możności duchowej ${ }^{66}$. Tak rozumiana dusza jest commensurata, czyli skierowana do ciała, które warunkuje relację poznania ${ }^{67}$. Nieco dalej Tomista dodaje:

64 Przedstawiana problematyka dotyczy wczesnego etapu pracy naukowej omawianego autora. Stanowi to pewną trudność interpretacyjną, ponieważ mogłoby się wydawać, że rozwiązania przedstawiane, oparte o tę problematykę, są już po prostu z jakiś względów nieaktualne. Jednak w nowszych publikacjach M. Gogacza możemy odnaleźć niejako „ślady” wcześniejszych rozwiązań lub wręcz zagadnienia, które bezpośrednio $z$ nich wynikają. Na przyklad w Elementarzu M. Gogacz pisze: „materia, gdy aktualizuje ją forma jest powodem szczegółowości i jednostkowości człowieka" - Elementarz metafizyki, 73. Por. opracowanie zagadnienia commensuratio u św. Tomasza z Akwinu i tomistów w: M. Krasnodębski, Dusza i ciało, Warszawa 2004.

65 Por. M. Gogacz, Egzystencjalne rozumienie duszy ludzkiej, Studia Philosophiae Christianae 6 (1970) 2, 11-14.

66 „intelekt możnościowy, podstawowa więc zdolność poznawcza duszy, jest w niej właściwą jej możnością jednostkującą ją jako formę i że ten intelekt stanowi - będąc możnością - konieczne podłoże intelektu czynnego, jako przypadłości stykającej duszę ze szczegółowymi przedmiotami poznania, zawierającymi możność w postaci materii lub ciała" - Tamże, 16.

67 Zob. M. Gogacz, Istnieć i poznawać, dz. cyt., 190; Por. także ujęcia commensuratio u M. Gogacza w: W. Mering, Spór o zasadę jednostkowienia duszy ludzkiej w tomizmie egzystencjalnym, Studia Pelplińskie 1978, 286-290; Tenże, Zagadnienie nieśmiertelności duszy ludzkiej w metafizyce tomizmu egzystencjalnego, Studia Pelplińskie 1977, 331-336. 
„traktując intelekt jako konieczną możność duszy, uniedoskonalającą i jednostkującą ją wewnętrznie w nieutracalny dla niej sposób (materia byłaby niekonieczną możnością uszczegóławiającą), pragnę tylko zaproponować poszerzenie zagadnienia commensuratio o zagadnienie strukturalnej, a nie tylko zewnętrznie działającej funkcji intelektu możnościowego wewnątrz duszy ludzkiej jako formy substancjalnej. Intelekt jest możnością, stąd też związane z nim commensuratio byłoby nie tylko nastawieniem psychicznym duszy na ciało, i nie tylko dawanym duszy przez Boga już od początku umniejszeniem formy, lecz byłoby wewnątrz duszy ontycznym czynnikiem strukturalnym, możnością, która jednostkuje, bo nastawia duszę na ciało dla zrealizowania poznania poprzez dane zmysłowe, dla ujęcia których dusza musi mieć szczegółowość, czyniąc ją tym oto człowiekiem"68. M. Gogacz zagadnienie commensuratio tłumaczy zawsze odwołując się do możliwości poznania zmysłowo - intelektualnego. Budzić to może wątpliwość, czy nie jest to zawężeniem tej problematyki tylko do aspektu intelektu komensurującego, czyli ostatecznie do aspektu poznawczego. Dodajmy jednak, że są to analizy wyznaczone ujęciem strukturalnym.

Można, naszym zdaniem, w ramach tomizmu konsekwentnego wskazać szersze rozumienie commensuratio, wzbogacone o uzasadnienia oparte o problematykę przyczyn celowych - czyli wskazać na ujęcie genetyczne. Podpowiedzią nich będzie wypowiedź $\mathrm{K}$. Wojcieszka ${ }^{69}$, który twierdzi, że stopień dopasowania obszarów poznawczych (możności duchowej i materialnej) zależy od przyczyn celowych. To one, jego zdaniem, niejako harmonizują te obszary bytowe, by możliwe było poznanie. Gdy spróbujemy przenieść tę „współpracę poznawczą" na płaszczyznę commensuratio to zauważymy, że jest ono wynikiem przyczynowania celowego. Obydwie możności w jakimś sensie nastawiają duszę na konkretne ciało. Intelekt możnościowy jednostkuje duszę, a ciało wprowadza w nią szczegółowość. Zatem i przyczyny celowe duszy (w aspekcie intelektu kommensurującego) i przyczyny celowe ciała (wnoszące w duszę szczegółowość) pośrednio tłumaczą commensuratio animae ad hoc corpus $\mathrm{w}$ ujęciu genetycznym.

Przyjrzyjmy się teraz ostatniemu zagadnieniu - istotowej stronie relacji osobowych i własności transcendentalnych $\mathrm{w}$ aspekcie przyczynowania celowego. Własności transcendentalne są przejawami istnienia ${ }^{70}$. Przejawiają się $w$ istocie,

68 M. Gogacz, Istnieć i poznawać, dz. cyt., 192-193. Commensuratio nie może być właściwością formy, ponieważ musiałoby być wyznaczone przez wlaściwe jej podłoże, a więc tym, co jednostkowałoby duszę byłby obecny w niej akt. Nie może też być relacją, ponieważ relacja jest przypadłością, a przypadłość nie może powodować zmian w obrębie istoty. Nie może być również forma od razu stworzona przez Boga jako naznaczona commensuratio, gdyż powodowałoby to zrezygnowanie $z$ tłumaczenia bytu poprzez wskazywanie na jego adekwatne przyczyny, wychodząc od zidentyfikowanych pryncypiów. Por. Tamże, 183-188; Por. M. Gogacz, Wokót problemú osoby, dz. cyt., 183.

69 Zob. wypowiedź K. A. Wojcieszka, zawartą w dyskusji nad referatem „Commensuratio” w odniesieniu do wladz poznawczych czlowieka na podstawie ujęć św. Tomasza, na posiedzeniu Katedr Historii Filozofii UKSW z 22.01.2004 zamieszczoną na: www.katedra.uksw.edu.pl/ramka.htm

70 M. Gogacz wymienia sześć własności transcendentalnych. Są to: odrębność, jedność, realność, prawda, dobro, piękno. - Zob. Elementarz metafizyki, 38. 
dlatego określa się je jako zamienne $\mathrm{z}$ bytem ${ }^{71}$. Choć $\mathrm{M}$. Gogacz nie pisze, w swych nowszych publikacjach, o tzw. istotowej stronie własności transcendentalnych, to w przypadku relacji osobowych, które są oparte na własnościach transcendentalnych, twierdzi, że taka strona tych relacji istnieje ${ }^{72}$.

Ciekawym „śladem” istotowej strony własności transcendentalnych są wczesne publikacje M. Gogacza ${ }^{73}$. Zagadnienie to zawsze pojawia się na horyzoncie rozważań dotyczących możliwości budowania relacjonistycznej teorii osoby ${ }^{74}$. Tam autor twierdzi wprost o budowaniu istotowej strony własności transcendentalnych przez przyczyny celowe ${ }^{75}$. Dodajmy, że za takie własności transcendentalne, na które wpływ mają przyczyny celowe, M. Gogacz uznał prawdę i dobro. To one, zdaniem autora, konstytuują się dzięki istnieniu i relacji $z$ innymi bytami ${ }^{76}$.

Gdy autor rozpatruje relację między bytami, to stwierdza, że dany byt wnosi w kształtowaną własność transcendentalną właściwość odbioru i akceptacji, a to $z$ kolei jest treściową stroną tej własności. To odróżnienie jest konsekwencją przyjęcia przez Tomistę, że wnoszone (kształtowane) treści nie są tym samym co istnienie $^{77}$. Dzięki temu, własności te, od ich strony istotowej, są np. ludzkie. Zachodząca tak relacja jest w pewnym sensie zwrotna. M. Gogacz wyjaśnia: „gdy bowiem inni ludzie, jako przyczyny celowe, oddziałując na danego człowieka kształtując kierunek jego własności transcendentalnych, stają się podmiotami relacji, których kresem są transcendentalia danej osoby. Tak zbudowana relacja jest przyczynowaniem celowym. Gdy z kolei dany czlowiek ukonstytuowaną w nim własnością prawdy lub dobra oddziaływa na ludzi, staje się podmiotem relacji, której kresem są inni ludzie. Tak zbudowana relacja jest $w$ danym człowieku relacją osobową o kształcie np. obecności, rozmowy, miłości”78.

71 Por. Elementarz metafizyki, 44-45. M. GogACz wyraźnie twierdzi, że będąc przejawianiem się istnienia $w$ całym bycie, własności transcendentalne przejawiają się zgodnie $\mathrm{z}$ istotą bytu.

72 „własność transcendentalna realności w dwu osobach spowodowała relację życzliwego współprzeżywania, akceptacji nazwanej upodobaniem. Realność wprost jest podstawą współprzeżywania, które się spełnia w upodobaniu, we wzajemnej akceptacji, stanowiącej istotową treść relacji budującej się na realności. Ta relacja stanowi miłość" - Tamże, 51.

73 Zob. np. M. Gogacz, Propozycja tomistycznej formuly relacjonistycznej teorii osoby, Studia Philosophiae Christianae 10 (1974) 2, 7-30.

74 Zob. M. Gogacz, Problem teorii osoby, Studia Philosophiae Christianae 7 (1971) 2, 47-65.

75 Zob. M. GogaCz, Wokól problemu osoby, dz. cyt., 211; Zob. M. GoGACz, Propozycja tomistycznej formuly relacjonistycznej teorii osoby, art. cyt., 15-16.

76 Zob. M. Gogacz, Wokół problemu osoby, dz. cyt., 211-212. Ciekawym wydaje się być bliższe przyjrzenie się temu zagadnieniu $w$ aspekcie historiozoficznym, ponieważ te transcendentalia określane są niekiedy jako relacyjne.

7 Zob. M. Gogacz, Wokól problemu osoby, dz. cyt., 212; Por. M. Gogacz, Propozycja tomistycznej formuly relacjonistycznej teorii osoby, art. cyt., 25-28.

78 M. Gogacz, Wokót problemu osoby, dz. cyt., 213. Teoria relacji osobowych uległa znacznej zmianie i np. w Elementarzu i w Człowiek i jego relacje spotykamy się z odmienną ich identyfikacją. Początki formułowania teorii relacji osobowych należy szukać w zagadnieniach związanych z relacjonistyczną teorią osoby. - Zob. M. GoGACz, Problem teorii osoby, art. cyt., 63. 
Takie rozumienie przyczynowania celowego istotowej strony własności transcendentalnych było próbą, dokonaną przez M. Gogacza, rewizji teorii osoby. W z zdecydowanej większości swych późniejszych prac Tomista nie powtórzył tych ustaleń. Trudno odpowiedzieć na pytanie czy te analizy stanowily początek dla sformułowania "nowej” teorii osoby. Wydaje się jednak, że ich „ślad” odnajdujemy w późniejszych zagadnieniach związanych subsystencją, np. mowie serca i zagadnieniach związanych z teorią osoby.

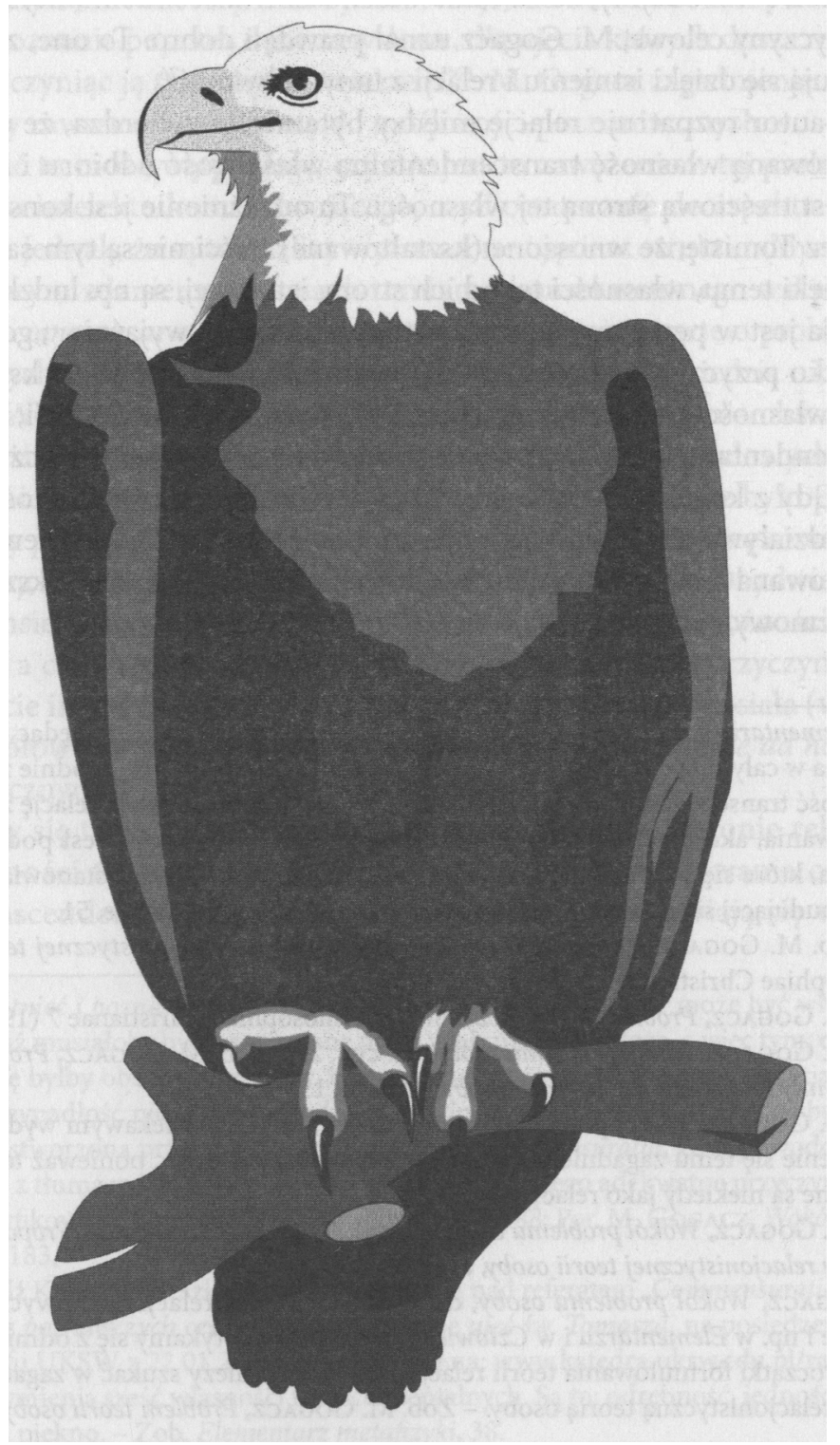

